\title{
In retrospect chosen by Philippe Janvier
}

\section{Les chiens aboient ("The dogs bark")}

by Herbert Wild

(1926)

This rare book had fallen into oblivion, but gained renewed interest with the recent "Gupta case” (see Nature 341, 16; 1989). It is a largely autobiographic novel about a similar case of palaeontological fraud - so far unresolved which shattered French geology between 1917 and 1922.

Herbert Wild, the author, is the pseudonym of Jacques Deprat (1880-1935), a talented French geologist accused of "salting" sites in Yunnan and northern Vietnam with fossil trilobites from Europe. Deprat was fired from the Geological Survey of Indochina in 1920 and banned from the Société Géologique de France. Instead, he became a successful writer, publishing 13 novels between 1924 and 1937. (One of them, Le Colosse endormi ("The sleeping Colossus"), a prophetic book about China, won the Grand Prix of the French of Asia, competing against André Malraux's La voie Royale.)

The Deprat case was revisited in detail in 1990 by a French geologist, Michel DurandDelga, who became convinced that Deprat was innocent. Yet no indisputable evidence for his innocence has ever been found, and the palaeontologist Jean-Louis Henry, an authority on trilobites, maintains that at least three of the suspected specimens were actually from Europe, presumably from Bohemia.

Deprat studied for his thesis at the Muséum National d'Histoire Naturelle in Paris under the supervision of the mineralogist Alfred Lacroix. After a stint as assistant professor in geology in Besançon, and on the recommendation of Pierre Termier, he became director of the Geological Survey of Indochina in Hanoi in 1909, at the age of 29.

Between 1909 and 1917, Deprat mapped much of southern China and northern Vietnam and published memoirs on the geological structure of Indochina. He reorganized the Geological Survey of Indochina, turning it into a centre for real scientific research (as opposed to routine engineering and mapping) and regularly published its scientific preoceedings. Initially, his only collaborator in palaeontology was Henri Mansuy, an elderly, self-made palaeontologist who was the first to describe the now famous Cambrian fossil sites of Yunnan. In 1914, however, he provided facilities to Madeleine Colani, a palaeobotanist and prehistorian, whom he trained and encouraged but who later became one of his fiercest critics.

Between 1909 and 1914, Deprat's boss was Honoré Lantenois, chief mining engineer for Indochina, a strange character who, although officially praising Deprat's skill, was jealous of his fame and disapproved of his lack of respect for his seniors. Lantenois left Indochina in 1914 on war service, but returned to Hanoi in February
1917. A month later, the Deprat case arose.

Deprat was at the peak of his fame national and international - when Lantenois called him into his office and, apparently embarrassed, told him that Mansuy had accused him (Deprat) of "salting" his fossil collections from Yunnan, Tonkin and northern Annam with European trilobites. Deprat was staggered, as Mansuy had never alluded to the deception. Two weeks later, Deprat returned to one of the suspected locations (Nui Nga Ma, now Nui Nguu Ma, an easily accessible hill near Ben Thuy, along the Hanoi-Saigon highway) and collected another fragment of the trilobite species he had recorded there in 1912. But this was apparently not enough to convince Lantenois.

Lantenois secretly sent the suspected samples to authorities in Paris (Lacroix, Douvillé and Termier) who concluded that the specimens were identical to species from Europe (Wales and Bohemia). In 1918, a committee of enquiry was sent to Nui Nga Ma but failed to find any fossils. There then followed a long and complex trial involving the Academy of Sciences and the Geological Society of France, but Deprat's undiplomatic behaviour steadily worsened his case and Lantenois' political influence and hatred of Deprat was decisive. Deprat was dismissed in November 1920.

Deprat would have been quickly forgotten by academics had it not been for the publication of Les chiens aboient. This novelistic account of his case seems accurate, yet the story of his discovery of an additional Ordovician trilobite in Nui Nga Ma in March 1917 remains contentious: neither I nor any Vietnamese palaeontologist has ever found fossils on this hill, a thick Mesozoic conglomerate overlying Ordovician quartzites.

The book caused turmoil in French geological circles, as several of the pseudonyms used were obvious; a complete 'key' was recently given to Durand-Delga by Deprat's daughter, revealing many other famous characters of French geology and palaeontology. Nevertheless, Les Chiens aboient was not a bestseller: only 2,500 copies had been sold by 1932 - and backbiters said that many had been purchased by Lantenois himself.

Although most of Deprat's geological work on Indochina was later authenticized by Jacques Fromaget, a famous specialist of this region, the mystery of the trilobites remains. The 10 specimens on which the Deprat affair rests were long considered lost but one of them has recently been rediscovered in a drawer at the Collège de France by Jacques Sigal. It is now in the Muséum National d'Histoire Naturelle in Paris.

Whatever sympathy one may have for Deprat, one must assume that the specimens are indeed apocryphal unless proved otherwise by new field investigations. How they reached Vietnam is unknown. Some accused Mansuy, who revisited France several times (unlike
Deprat, who did not return until 1919). Had Deprat perpetrated the fraud, why did his samples include only a few trilobites among the thousands of other fossils he carefully collected for stratigraphy? And why would he have ruined a promising career with such a useless deception? It seems entirely at odds with his personality and the integrity of his other work.

All the protagonists of the Deprat case are now dead. Deprat died in a climbing accident in the Pyrenees in 1935; ironically, his last novel, $L a$ paroi de glace ("The ice wall"), published posthumously in 1937, is a detective story dealing with just such an accident. The clue to the case may one day turn up in a document hidden in a drawer somewhere in Vietnam or Paris. Until then, we eagerly await an English translation of Les chiens aboient annotated by a historian of geology.

Philippe Janvier is at the Laboratoire de Paléontologie, Muséum National d'Histoire Naturelle, 8 Rue Buffon, 75005 Paris, France.

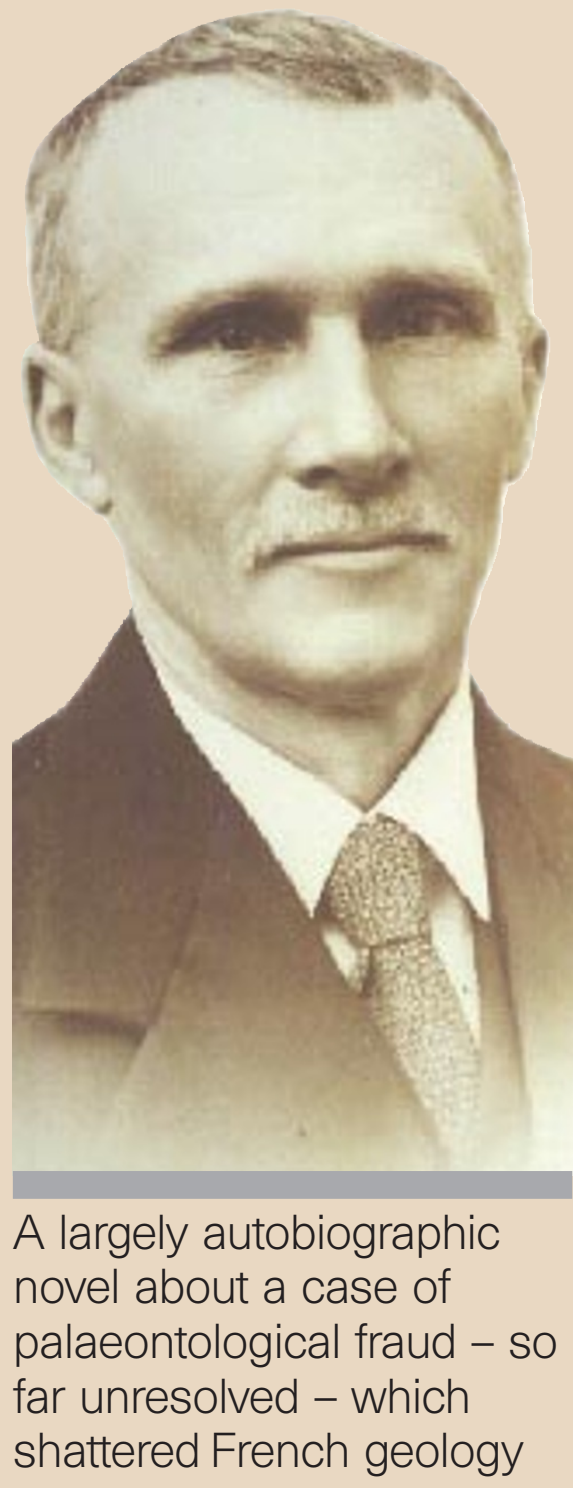

